\title{
Counselling Practices in Fostering Potentials among Gifted Students
}

\author{
Grace Annammal Piragasam*
}

Special Education Department, Faculty of Education and Human Development, Universiti Pendidikan Sultan Idris, 35900 Tanjung Malim, Malaysia

*Corresponding author: grace@fppm.upsi.edu.my

\begin{abstract}
The role of a school counsellor is inevitably vital in the process of holistically developing students. Counsellors are generally known for initiating career path and guidance apart from engaging students into various academic and co-academic programs to elevate individual potentials. However, little is known pertaining practices in counselling that serves gifted students to its best. Similarly, the existence of a good rapport between school counsellors and gifted students has not shed its light in recent studies. The purpose of this study was to facilitate the concern in providing counselling as to what gifted students' expectation would be in terms of counsellors' approaches and support services which are delivered. Findings indicated that counselling services is less favored by gifted students as an impact of relatively lack of knowledge of the particular counselling needs of the gifted students. Thus, there is a need arising to shape counsellors' awareness in dealing with gifted students on a better platform. Measures to establish students' confidence in counsellors should also be promoted, considering the need for counsellors to put gifted students in their perspective of professions.
\end{abstract}

Keywords: School counselling; counselling practices; gifted students; performing arts; advocacy

\begin{abstract}
Abstrak
Peranan guru kaunselor sekolah adalah sangat penting dalam proses pembentukan murid yang holistik. Guru kaunselor lazimnya bertanggung jawab untuk menyediakan sokongan dan panduan kerjaya untuk murid di sekolah. Peranan guru kaunselor termasuklah merangka serta melaksanakan program akademik dan ko-akademik untuk meningkatkan potensi individu murid. Walau bagaimanapun tidak banyak diketahui tentang amalan kaunseling yang ditawarkan untuk murid pintar dan berbakat. Di samping itu, situasi hubungan di antara antara guru kaunselor dengan murid pintar dan berbakat tidak banyak dilaporkan dalam kajian kebelakangan. Kajian ini bertujuan untuk menyelidik kepentingan khidmat kaunseling bagi memenuhi jangkaan murid pintar dan berbakat khususnya dari aspek pendekatan dan khidmat sokongan yang diberikan oleh guru kaunselor di sekolah. Kajian ini mendapati bahawa perkhidmatan kaunseling di sekolah kurang mendapat sambutan dalam kalangan murid pintar dan berbakat. Hal ini adalah impak daripada guru kaunselor kurang pengetahuan untuk menyediakan maklumat yang bersesuaian serta menjangkaui keperluan murid pintar dan berbakat. Oleh yang demikian, kesedaran dalam kalangan guru kauselor untuk menangani murid pintar dan berbakat perlu diambil perhatian khususnya untuk membimbing mereka dalam bidang keupayaan dan bakat yang dimiliki oleh murid tersebut. Selain itu, terdapat keperluan untuk membina keyakinan murid pintar dan berbakat tentang perkhidmatan dan sokongan guru kaunselor di samping menggalakkan guru kaunselor itu sendiri untuk merangkumkan murid pintar dan berbakat dalam perspektif profesionalisme mereka.
\end{abstract}

Katakunci: Kaunseling sekolah, amalan kaunseling; murid pintar; seni persembahan; sokongan

(C) 2017 Penerbit UTM Press. All rights reserved

\subsection{INTRODUCTION}

Giftedness is often described as the conditions that produce achievements. Trapped by the metaphor of "gifts," the common myth is believed that the most important aspect of being gifted is the ability to turn gifts into recognizable and valued accomplishments. The growing emphasis on talent development, fosters an achievement orientation rather than on the basis of the child's inherent worth instead (Gagne, 1995; Rimm, 1997). Emphasis on achievement and success leads towards biased measurement of a student's worth in terms of his or her accomplishments. This certainly prohibits the discovery of the student's inner agenda in the attempts to serve educational goals for the gifted that contain values and ideas for action particularly among school counsellors.

The models and theories set by proponents of gifted education unveil their sincere desire to maximize giftedness as much as possible on how the gifted think, feel, and experience. Gagné $(1995 ; 2003)$ for example, has developed a model which differentiates between giftedness and talent where he proposes that giftedness relates to distinctly above average competence in the ability domains of intellect, creativity, socio-emotional, sensory-motor and others, while talent relates to above average performance in talents, such as music, sport and art. He identifies the role of the environment and internal factors contributing to the transformation of talents into gifted performances.

To cultivate a culture of excellence in all schools, supportive measures to provide challenging, stimulating development experiences and opportunities that enable gifted students to explore and build on their gifts and talents are required. At this juncta, school counsellors as qualified and specially trained teachers are exposed to most serving multiple group students over the course of their working days. Consequently, their workload is very heavy and schools will prioritize the tasks that they require of the school counsellor. Nevertheless, school counsellors are also called to assist in providing assistance based on counselling approaches to meet various needs of gifted students (Vialle et al., 2007). This assistance and support includes vast range of services regarding gifted services, and promoting an understanding and awareness of gifted students' unique needs. 


\subsection{ISSUES RELATED TO COUNSELLING}

Traditionally, education of the gifted has focused on students' cognitive abilities and has ignored their social and emotional needs (Biddick, 2009; Peterson, 2009; Versteynen, 2005). Consistently it is agreed in the findings of e previous researches that gifted children have unique affective characteristics and needs (Gross, 1997; Mendaglio \& Tillier, 2006; Piechowski, 2006). Gifted children not only think differently they feel differently (Gagne \& Garnier, 2004). Some gifted individuals possess a level of emotional sensitivity and intensity that sets them apart from others. Empirical evidence, however, does not support the perception that individuals who are gifted have higher levels of social or emotional problems than the general population, (Bain \& Bell, 2004; Bain et al., 2007).

Attitudes toward social problems of the gifted have historically been evaluated by gathering evidence that supported concerns about emotional and social problems in children who are gifted (Bailey, 2011). This may be due to the fact that it is only when a gifted and talented child exhibits behaviour problems that they are referred for specialist help and therefore the incidences of social and emotional problems are recorded. Teachers and parents seem more inclined to label children identified as gifted as difficult, odd, or unhappy. Perceptions that giftedness is typically associated with serious social and emotional problems may, indeed, cause harm in terms of expectations as well as potential misinterpretation of resources to support students who are gifted. Again, because when gifted children are not displaying any negative behaviour they go un-noticed and simply do not meet the ends.

School counsellors then, need to provide a responsive development environment if gifted and talented children's social and emotional needs are to be met. Berkowitz and Hoppe (2009) described the responsive environment as cognitive behavioural approach in counselling. Flexibly, structured environment of counselling has the ability to meet all learners' needs at their present level of cognitive, emotional, social, physical, and intuitive development and to help them move on from that point. In this approach, gifted students can pursue interests in depth with a minimum time limitations. They are no longer singled out, but school counsellors can group the students flexibly with other students as their learning needs demand, or they can work individually whenever it is more appropriate. The responsive environment can also be incorporated in the classroom. The aim is to offer opportunities for higher level thinking, creative thinking and original student research.

Gifted students mature faster from their typically achieving age mates, it is important to be mindful of their developmental phases in life in which gifted students are expected to thrive. There is no one-size-fits-all description for a gifted child as is the case in the general population. What drives and motivates one gifted child will turn off another. The optimizing of potentials should be student centered allowing the students to explore in depth areas of expertise and interest. Gifted students tend to be more interested in an open, flexible learning environment which is more conducive to the deep, intense knowledge and ideas that benefits them (Vaingankar, 2010). The school counsellor's role in such condition ought to be facilitator, a fellow explorer by will, rather than making decisions on students' life or growth. The design and implementation of counselling sessions differs according to the type of gifted students. Instead of self planned sessions or approaches of counselling and very little opportunity for gifted students to assess themselves, counsellors may consider and arrange suitable plans for allowing effective counselling by first knowing the students personality and areas needed for counselling (Freeman, 2005; Wood, 2010). Counselling services must be centralized on the students opportunity to get up and move to the next level as they find directions and support to maximize their potentials as well as to know their purposes in life.

\subsection{MEETING THE NEEDS FOR COUNSELLING THE GIFTED STUDENTS}

The No Child is Left Behind of 2001 (NCLB) was established to close the achievement gap and to ensure that all students receive equitable and fair educational opportunities by highly qualified teachers in designated subject areas. According to NCLB, students have the right to obtain an education of high quality, which is delivered by highly qualified teachers. Although NCLB mentions children of exceptional learning needs, which include the gifted and talented as well as children with disabilities, much greater attention has focused on the latter group (NCLB, 2001). Educational programs including counselling services lack the focus on identifying and instructing gifted and talented students. There is currently no standard requirement that teachers be highly qualified or receive specialized training in order to work with the gifted and talented population (NAGC, 2008). Not only is this a disservice to gifted and talented students, but the lack of understanding of the unique population needs may lead to decision making that is actually detrimental to these students.

One of these factors is the false belief that gifted and talented students do not experience academic concerns (Crepeau-Hobson \& Bianco, 2010), do not display behavioural problems, and do not have needs which cannot be fully met in the general educational setting (Bell \& Roach, 2001). A proper evaluation for gifted support services should examine multiple factors that could impact upon the demonstration of the giftedness. Hence, gifted children may best learn when their strengths are being utilized with the help and support of school counsellors, and their needs are being met through best practices.

The reasons that the gifted population has not received sufficient attention can be due to a general lack of consensus between school teacher and counsellors regarding how to approach the evaluation of students, how best to support giftedness in the school setting, how to interpret their abilities, and how to program appropriately counselling sessions for these students (Colangelo \& Wood, 2015). Currently, there is a "one size fits all" model applied to children who fall under the umbrella of gifted and talented. Part and parcel of this model, is the over-reliance on the use of intelligence tests as markers for self autonomy and independence among gifted students. In turn, this practice does not lend to gifted students appropriate support and services in the school as they deserve (Nweze \& Okolie, 2014). The purpose of this study is to provide information on what strategies or "best practices" frequently occurring in the school counselling setting and which academic and career interventions and services that gifted students would like to see included in their school counselling programs. This study also seeks to determine the students' experiences with these suggested "best practices" in school counselling from the students' point of view. 


\subsection{METHODOLOGY}

Observational case studies often focus on a classroom, group, teacher or pupil, often using a variety of observations and interview methods as their major tools (Burns, 2000). In this study, gifted students in particular educational contexts were at the core of the research, and interviews were the primary methods of data collection. In this case study, it was intended to produce results for predictable reasons (Burns, 2000). Students who were identified, were approached to participate in a focus interview. The interview comprised open-ended questions that probed on counselling services in their respectively schools. Questions posted included participants' perception about counselling services in their existing schools, preferred counselling services, reasons for seeking counselling services, and the counsellor's approach preferred by the students. Examples of questions were:

1. Tell me about the counselling programs implemented in your school?

2. Would you seek your school counsellor and for what purposes?

3. What would be your expectation from a school counsellor before seeking their support and services?

\section{Participants}

Participants were 18 gifted and talented adolescents in Malaysia identified as gifted and talented in performing arts and sports. This study used a non-random, selective sampling procedure, as particular educational environments were at the core of the research, and participants were selected accordingly. It was intended that the case study design would allow the perspectives of gifted students to be included, so as to strengthen the breadth, depth, and credibility of the findings. Malaysia conceptualized gifted students as per the National Education Development Blueprint (PPPM) report as students whose abilities and potential for accomplishment in six areas of aptitudes (intellectual, specific academic, technical and practical arts, visual and performing arts) which are so outstanding that they require special programs to meet their educational needs (PPPM, 2013). Participants were identified as gifted and talented by demonstrating outstanding abilities or potential for accomplishments performance-base criteria and portfolios. According to Piirto (1999) and Renzulli (2001), gifted and talented students represent the top $15 \%$ of a school population. However, many of these students had been accepted to enroll in the National Sports School. The age of the participants of this study ranged from 15 to 17 years old.

\subsection{RESULTS}

The following sections introduce the results of the study. The results are presented as semi-narratives through descriptive and exploratory categories in order to keep the richness of the participants' experiences intact. The entire findings describe many facets of counselling service in the school particularly in the perspective of serving the needs of the gifted students.

\section{Limitation Of Counselling Services}

The findings of this preliminary study confirmed that gifted and talented students made a few important considerations before approaching school counsellors. School counsellors should first win the confidence of the participants by the expressions and mode of handling since these indications portrayed their effectiveness and knowledge to helping gifted students. In many responds during the interview, participants reported that they were unconvinced and fear that school counsellors relatively lack the knowledge of the particular counselling needs of the students. For many school counsellors, their work with gifted students is imbalanced and limited toward testing and problem behaviours at the expense of more positive interventions, including advocacy. Participants expressed that the school counsellors were not doing enough for them since majority counselling sessions are academic on nature.Examples of such expressions are narrated below:

..we get to meet the counsellors often during exam seasons or whenever there are programs on academic excellence (Yang).

..I know that many students are referred to counsellors when discipline issues arise, so I wonder if they could help me (Rais).

..I have a lot of matters to open up to someone whom I am only convinced to share with. He or she must be able to visualize my positions emphatically or else it is a waste of time and I rather handle it myself (Bob).

Counsellor Training And Readiness

Participants reported that school counsellors were not fully trained to counsel students with special needs, which might also include those who are gifted in their school. This was an unfavourable situation reported by participants and had exacerbated the heavy demands on their energy and achievements set by the school. Unfortunately, in many cases participants were not directly motivated or recognized by school counsellors for any reasons even on occasions of their victory in a competition. The gap in the relationship between the participants and the school counsellors had impacted negative impressions on the competency level of rendering counselling services and support to participants. Participants also reported that in certain cases they were avoided by school counsellors, expressed as follows:

..I don't remember when I was ever appraised by my school counsellors. We are lined up for prize giving ceremonies during assembly and that is all. So I don't see if my real self is seen as a person (Mira).

..sometimes I just feel like saying give me a break, it is so tiring returning from a long duration of practice and tournament and there you go..it's time to buck up on getting on school targets. I mean is there any other options for counselling that I can think of? (Latifah). 


\section{Time Factor}

Other school priorities often deflected school counsellors away from getting to know and helping participants in advance. Their lack of time impacted significantly, on how they could assist gifted students, their families and their teachers. In such cases, participants turned towards their subject teachers who possessed better understanding and were able to advocate for directions in life and decision making. In order to readdress the issue, it is proposed that help and support may come on participants' way if school counsellors spread their time across their various roles in the schools they serve. Examples of such expressions are narrated below:

Counsellors are always busy; they take students on trips and are catching up schedules on workshops. It is a bit taxing to see their conditions and definitely that's one of the reason I do not approach them (Hanif).

I like my school counsellors, they are nice and kind. But, I can't talk to them personally because often they are not in the room. Sometimes they replace classes of teachers who are not around in school (Ummi).

..to me, my favourite teacher is my best buddy..he knows me in and out. He coaches me throughout the year and we spend our time mostly together. If a problem occurs, he will be my source of reference (Bob).

\section{Area of Discourse}

According to participant responses in this study, there were very few topics that could be discussed during counselling. Although apart from students' career, the responsibility of school counsellors is to help on intra-personal developments. However, participants underscored the need for counsellors to address their experiences with mixed emotions, confusion about meanings and definitions of giftedness, lack of understanding from others, fear of failure, challenges as well as difficulties in finding peers with the same wave-length. Clearly, few of these topics were experienced in counselling session by the participants in this study. Participants reported that they experienced being in counselling sessions pertaining their contribution to society, expectations they had of themselves, and expectations others had of them. In so many ways this is expressed as below:

I have passion for sports. There are matters which I think my school counsellor could not help. For example stress, anxiety and meeting my toughest opponent in the upcoming event..not that the counsellors can't but their sharing of mind does not hit my expectations (Susy).

..it is almost all about my achievement for the school and keeping the academic records of the school on track. That is why I hesitate to speak up on my personal matters like issues related friendship. Does it really matter after all, I guess (Mikail).

..there are many issues I am facing right now, for example I am financially constrained and that is the main thing hindering me from performing better. But I can't share this with my school counsellors, I am ashamed and I don't know if she could help and fear that my problem may leak out (Mohd).

\section{Best Counselling Practices}

Participant expressed that personality plays the law of attraction factor towards seeking counselling services. Counsellors who somehow do not reflect confidence in knowledge and skill of serving gifted students will be undoubtedly avoided and thus the relationship between both parties may not evolve although the needs for counselling do exist. Participants responded that successful and significant individual who had careers in similar fields of talent or interest would be beneficial and meaningful. Participants also felt that discourses besides tracking on academic targets, other aspects of counselling might be extended to time management or leadership skills. Since school counsellors often organize programs on career and motivation, participants indicated that these programs might be more discretely planned for gifted students for mentoring or programs on life development. Designing a career path in accordance with their talents, interest, and goals in mind would be helpful to draw participants closer towards school counsellors.

\subsection{CONCLUSION}

Results of this study point the need for school counsellors to be aware of the wide variety of best practices that can be used in working with their gifted students to implement them. Additional it is from this study also clearly highlight that the importance of the school counsellor's relationship with their gifted students are underscored. Apart from that counselling services in most of the schools are ineffective in rendering support and services for gifted students due to the lack of thorough understanding of basic traits and characteristics of gifted psychology and function. A suggestion might be to enhance the competency and knowledge of school counsellors in the area of gifted education. The extension of training on different group of students will expand school counsellor's readiness and ability to plan and develop programs especially catering for the need of gifted students. This is an essential move to draw more positive impressions on counselling services in schools where gifted and talented students are placed. However, to do so, school counsellors must be exposed to and be familiar with both sets of typical and gifted students standards.

The findings from this study also emphasize the importance of training school counsellors in their preparatory programs in the psychology and unique needs of gifted learners as well as how to structure school counselling programs to reflect the best practices in the literature. Currently most school counsellors do emphasize on gifted learners in either life span development or even issues related to emotions and feelings. Hence, opportunities may be seen on school counsellors to re-establish the connections for mentoring and their services to gifted students in developing their skills in various domains of aptitudes. School counselling programs may investigate how this information may be beneficial if the desire to fulfill the idea of NCLB is applied to all including the gifted students. 


\section{References}

Burns R. (2000), Introduction to Research Methods. London: Sage Publications.

Bailey, C. L. (2011). An Examination Of The Relationships Between Ego Development, Dabrowski's Theory Of Positive Disintegration, And The Behavioural Characteristics Of Gifted Adolescents. Gifted Child Quarterly, 55(3), 208-222.

Bain, S. K. \& Bell, S. M. (2004). Social Self-Concept, Social Attributions, And Peer Relationships In Fourth, Fifth, And Sixth Graders Who Are Gifted Compared To High Achievers. Gifted Child Quarterly, 48(3), 167-178.

Bain, S. K.; Bliss, S. L.; Choate, S. M. \& Sager Brown, K. 2007. Serving Children Who Are Gifted: Perceptions Of Undergraduates Planning To Become Teachers. Journal for the Education of the Gifted, 30(4), 450-478, 535-537.

Bell, C. D. \& Roach, P. (2001). A New Problem For Educators: Identification Of The Non-Achieving Gifted Student. Education, 107, 178-181.

Berkowitz, M. W. \& Hoppe, M. A. (2009). Character Education And Gifted Children. High Ability Studies, 20(2), 131-142.

Biddick, M. 2009. Cluster Grouping For The Gifted And Talented: It works. APEX, 5(4):78-76. Retrieve from http://www.giftedchildren.org.nz/apex/.

Colangelo, N., \& Wood, S. M. (2015). Introduction to the Special Section: Counselling the Gifted Individual. Journal of Counseling \& Development, 93, 131-132.

Crepeau-Hobson, F. \& Bianco, M. (2011). Identification Of Gifted Students With Learning Disabilities In A Response-To-Intervention Era. Psychology in the Schools, $48(2), 102-109$

Freeman, J. (2005) Counselling The Gifted And Talented. Gifted Education International, 19, 245-252.

Gagné, F. (1995). From Giftedness To Talent: A Developmental Model And Its. Roeper Review, 18, 103.

Gagné, F. (2003). Transforming gifts into talents: The DMGT as a Developmental Theory. In N. Colangelo \& G.A. Davis (Eds.), Handbook of Gifted Education. Third Edition, 60-74. Boston: Allen \& Bacon.

Gagne, F. \& Gagnier, N.(2004). The Socio-Affective And Academic Of Early Entrance To School. Roeper Review, 26, $128-138$.

Gross, M. U. M. (1997). How Ability Grouping Turns Big Fish Into Little Fish - Or Does It?: Of Optical Illusions And Optimal Environments. The Australasian Journal of Gifted Education, 6(2), 18-30.

Mendaglio, S. \& Tillier, W. (2006). Dabrowski's Theory Of Positive Disintegration And Giftedness: Over Excitability Research Findings. Journal for the Education of the Gifted, 30(1), 68-87.

NAGCM, (2008). What is Giftedness? Retrieved from http://www.nagc.org/WhatisGiftedness.aspx.

NCLB (2001). No Child Left Behind. Retrieved September 30, 2015 from www.isbe.net/nclb.

Nweze, T., \& Okolie, U. C. (2014). Effective Guidance and Counselling Programmes in Secondary Schools: Issues and Roles in Students' Career Decision Making. IOSR Journal of Research \& Method in Education (IOSRJRME), 4, 63-68.

Pelan Pembangunan Pendidikan Malaysia. 2013-2025. Bab 7 Struktur Sistem. Retrieved August 16, 2015 from http:www.moe.gov.my/userfiles/file/PPP/ PreliminaryBlueprint-BM.pdf.

Peterson, J. S. (2009). Myth 17: Gifted And Talented Individuals Do Not Have Unique Social And Emotional Needs. The Gifted Child Quarterly, 53(4), $280-282$.

Piechowski, M. (2006). "Mellow Out," They Say. If I Only Could. Intensities and Sensitivities Of The Young And Bright. Gifted Child Quarterly, 52(1), 102-104.

Rimm, S. B. (1997). Underachievement Syndrome: A National Epidemic. In N. Colangelo \& G. A. Davis (Eds.), Handbook of Gifted Education. Second Edition (pp.416-434). Boston: Allyn \& Bacon.

Versteynen, L. (2005). Issues in The Social And Emotional Adjustment Of The Gifted Children: What Does The Literature Say? New Zealand Journal of Gifted Education. Retrieved from http: //www.giftedchildren.org.nz/apex/v13art04.php.

Vialle, W., Heaven, P. C. L. \& Ciarrochi, J. (2007). On being Gifted, But Sad And Misunderstood: Social, Emotional, And Academic Outcomes Of Gifted Students In The Wollongong Youth Study. Educational Research And Education, 13(6), 569-586.

Wood, S. (2010). Best Practices In Counseling The Gifted In Schools: What's Really Happening. Gifted Child Quarterly, 21(2), 133-145. 